\title{
PERILAKU PELAT FERROFOAM CONCRETE DENGAN DAN TANPA POZOLAN AKIBAT BEBAN IMPACT
}

\author{
Muhammad Maulana ${ }^{1)}$, Abdullah ${ }^{2)}$, Yunita Idris ${ }^{3)}$ \\ ${ }^{1)}$ Magister Teknik Sipil, Universitas Syiah Kuala, Banda Aceh 23111, Indonesia \\ 2),3) Jurusan Teknik Sipil, Universitas Syiah Kuala, Banda Aceh 23111, Indonesia \\ email: mmaulana@mhs.unsyiah.ac.id ${ }^{1)}$, abdullahmahmud@unsyiah.ac.id ${ }^{2)}$, \\ yunita.idris@unsyiah.ac.id ${ }^{3)}$
}

DOI: http://dx.doi.org/10.29103/tj.v11i1.378

(Received: September 2020 / Revised: November 2020 / Accepted: November 2020)

\begin{abstract}
Abstrak
Konstruksi non struktural rentan rusak akibat beban impact. Salah satu upaya menanganinya dengan menggunakan ferosemen yang mampu memberikan daya tahan kejut dengan baik. Matriks ferosemen dapat berinovasi menggunakan beton ringan yang telah banyak digunakan, salah satunya memakai busa yang dinamakan menjadi ferrofoam concrete. Tujuan penelitian ini mengamati kapasitas beban impact terhadap ferrofoam concrete dengan pasir pozolan dan tanpa pasir pozolan sehingga dapat digunakan pada konstruksi dengan tingkat ketahanan kejut yang besar. Sebanyak 4 benda uji pelat memiliki dimensi penampang $400 \mathrm{~mm}$ dengan ketebalan $40 \mathrm{~mm}$ digunakan dan 4 lapis wiremesh ditetapkan. Perbedaan SG $1200 \mathrm{~kg} / \mathrm{m}^{3}, 1400 \mathrm{~kg} / \mathrm{m}^{3}$ dan $1600 \mathrm{~kg} / \mathrm{m}^{3}$ menjadi pertimbangan dengan FAS 0.4 dan penambahan $10 \%$ pasir pozolan ditentukan. Pengujian beban impact diaplikasikan terhadap pelat dengan menjatuhkan bola besi sebesar $3 \mathrm{~kg}$ dari ketinggian $1 \mathrm{~m}$ di tengah pelat. Penentuan kerusakan dampak ditunjukkan dengan penyerapan energi disebabkan retak awal hingga retak keruntuhan dan defleksi selama peristiwa tumbukan. Hasil menunjukkan bahwa kinerja mortar ringan pada SG 1.4 Pozolan lebih baik dari SG 1.6 Pozolan, SG 1.2 Pozolan dan SG 1.4 Non Pozolan dalam menyerap energi akibat beban impact.
\end{abstract}

Kata kunci: ferrofoam concrete, impact test, pozolan, drop-weight test

\begin{abstract}
Non-structural constructions are prone to damage due to impact loads. One of the efforts to overcome this problem is by using ferrocement which is able to provide good shock resistance. The ferrocement matrix can innovate using lightweight concrete which has been widely used, one of which uses foam which is known as ferrofoam concrete. The purpose of this study was to observe the impact load capacity on ferrofoam concrete with Pozolan sand and without Pozolan sand so that it can be used in constructions with a high level of shock resistance. A total of 4 plate specimens having a cross-sectional dimension of $400 \mathrm{~mm}$ with a thickness of $40 \mathrm{~mm}$ were used and 4 layers of wiremesh were assigned. The difference of SG $1200 \mathrm{~kg} /$ $\mathrm{m}^{3}, 1400 \mathrm{~kg} / \mathrm{m}^{3}$ and $1600 \mathrm{~kg} / \mathrm{m}^{3}$ was taken into consideration with FAS 0.4 and the addition of $10 \%$ pozolan sand was determined. The impact load test is applied to the plate by dropping an iron ball of $3 \mathrm{~kg}$ from a height of $1 \mathrm{~m}$ in the center of the plate. Determination of impact damage is indicated by the energy absorption due to initial crack to crack collapse and deflection during the impact event. The results show that the performance of ferrofoam with pozolan at SG 1.4 is better than SG 1.6, SG 1.2 and SG 1.4 without pozolan in absorbing energy due to impact loads.
\end{abstract}

Keywords: ferrofoam concrete, impact test, pozolan, drop-weight test 


\section{Latar Belakang}

Konstruksi pada bangunan memiliki kerentanan kerusakan akibat beban tumbukan (impact), salah satunya yang disebabkan dari kecelakaan lalu lintas. Kerusakan ini dapat terjadi pada konstruksi struktur kolom, dinding bata, pagar, atau lainnya. Respon yang dihasilkan mempengaruhi struktur konstruksi maupun struktur pendukungnya sehingga memerlukan ketahanan yang cukup besar dan bagaimana cara meningkatkannya adalah dengan penggunaan teknologi ferosemen. (Anonim, 1988) mendefinisikan "ferosemen sebagai jenis beton bertulang dinding tipis yang biasanya dibuat dari mortar semen hidrolis yang diperkuat dengan lapisan jarak dekat dari kawat jala kontinu dan berukuran relatif kecil. Kawat jala dapat dibuat dari logam atau bahan lain yang cocok". Disamping itu juga, mampu memberikan ketahanan kejut dalam perilaku retak. Berbagai jenis uji metode telah digunakan oleh peneliti untuk memperoleh beban impact karena kurangnya metode standar untuk pengujian ini. ((Abdullah et al., 2003)) yang melakukan program eksperimental mengenai panel komposit berdinding tipis dengan pembebanan missile impact untuk mempelajari perilaku dasar panel yang mengalami dampak pembebanan berkecepatan tinggi sehingga memungkinkan digunakan sebagai struktur pelindung dalam rencana pembangkit listrik bertenaga nuklir terhadap dampak rudal. (Abdullah, 2016) menyimpulkan dari studi eksperimentalnya bahwa peningkatan jumlah tulangan wiremesh dan penambahan butiran steorofoam pada panel ferosemen meningkatkan penyerapan energi dari dampak drop-weight test pada permukaan spesimen yang memungkinkan berguna pada pertahanan militer.

Diketahui material penyusun ferosemen tidak menggunakan agregat kasar, maka penggunaan material beton ringan menggunakan busa dapat menjadi salah satu alternatif pada ferosemen karena keuntungannya tidak terlepas dari berat busa yang dapat mereduksi beban konstruksi. Pengembangan beton ringan telah dilakukan (Abdullah and Bermansyah, 2007) sejak tahun 2006 menggunakan beton busa. Hasil yang diperoleh dari mutu beton ringan busa pun cukup tinggi dan dapat digunakan sebagai bahan pada elemen struktural (Abdullah et al., 2010). Penggunaan bahan pengisi sebagai agregat ringan pada beton busa seperti pozolan yang memiliki sifat mengikat layaknya semen dapat meningkatkan kinerja kuat tekan dan menjadi lebih ekonomis. Oleh karena itu, tujuan penelitian ini mengetahui kapasitas peredaman energi impact pada pelat ferosemen yang diperbaharui menggunakan beton ringan busa (menjadi ferrofoam concrete) dengan pozolan sebagai agregat ringan. Data yang dihasilkan dalam percobaan ini akan berfungsi sebagai informasi tambahan dasar dan umum yang berguna untuk penelitian di masa mendatang pada pelat serta menjadi alternatif pilihan aplikasi konstruksi.

\section{Metode Penelitian}

\subsection{Tes Spesimen}

Sebanyak 4 pelat benda uji ferrofoam concrete diproduksi dan diuji impact dan siklus defleksi yang meningkat secara bertahap selama peristiwa pukulan. Setiap spesimen dirancang memiliki dimensi penampang $400 \mathrm{~mm}$. Pembebanan uji impact dengan mekanisme uji drop-weight diterapkan ke spesimen pada bagian tengah permukaan pelat. Gambar 1 mengilustrasikan geometri spesimen. 


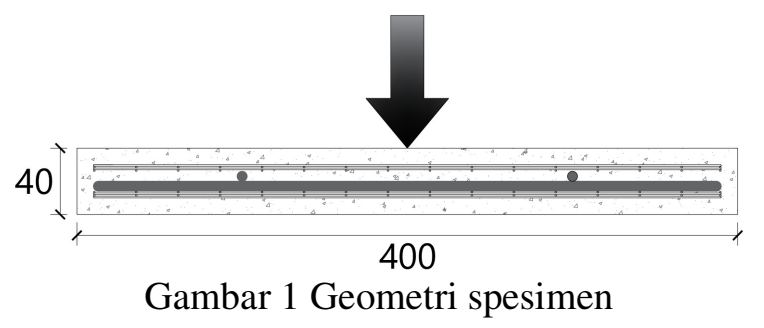

Empat dari spesimen ferrofoam concrete memiliki variabel diantaranya satu spesimen dibuat non pozolan dan tiga spesimen dibuat menggunakan pasir pozolan. Setiap spesimen memiliki penulangan sebagai konstruksi rangka dan dilapisi wiremesh. Masing-masing memiliki ketebalan $40 \mathrm{~mm}$. Tabel 1 memberikan ringkasan detail spesimen.

Tabel 1 Detail spesimen

\begin{tabular}{|c|c|c|c|c|c|c|c|c|}
\hline \multicolumn{5}{|c|}{ Spesimen } & \multicolumn{4}{|c|}{ Penulangan } \\
\hline \multirow[t]{3}{*}{ Nama } & \multirow[t]{3}{*}{ SG } & \multirow[t]{3}{*}{ Pozolan } & \multirow[t]{3}{*}{ Dimensi } & \multirow[t]{2}{*}{ Tebal } & \multicolumn{2}{|c|}{ Tulangan Baja } & \multicolumn{2}{|c|}{ Kawat Jala } \\
\hline & & & & & \multirow{2}{*}{$\begin{array}{c}\text { Diameter } \\
(\mathrm{mm})\end{array}$} & \multirow{2}{*}{$\begin{array}{c}\text { Jarak as } \\
(\mathrm{mm})\end{array}$} & \multirow{2}{*}{$\begin{array}{c}\begin{array}{c}\text { Bukaan } \\
(\mathrm{mm})\end{array} \\
\end{array}$} & \multirow{2}{*}{$\begin{array}{c}\text { Jumlah } \\
\text { lapis }\end{array}$} \\
\hline & & & & $(\mathrm{mm})$ & & & & \\
\hline $1.4 \mathrm{NP}$ & 1.4 & $0 \%$ & \multirow{4}{*}{$400 \times 400$} & \multirow{4}{*}{40} & \multirow{4}{*}{ P6 } & \multirow{4}{*}{200} & \multirow{4}{*}{25,4} & \multirow{4}{*}{4} \\
\hline $1.2 \mathrm{P}$ & 1.2 & \multirow{3}{*}{$10 \%$} & & & & & & \\
\hline $1.4 \mathrm{P}$ & 1.4 & & & & & & & \\
\hline $1.6 \mathrm{P}$ & 1.6 & & & & & & & \\
\hline
\end{tabular}

\subsection{Sifat Material}

\subsubsection{Beton ringan}

Dalam pembuatan spesimen uji digunakan tiga campuran specific gravity beton yang berbeda, yakni $1200 \mathrm{~kg} / \mathrm{m}^{3}, 1400 \mathrm{~kg} / \mathrm{m}^{3}$ dan $1600 \mathrm{~kg} / \mathrm{m}^{3}$. Campuran material beton berasal dari beton ringan busa. Rasio air-semen 0.4 yang digunakan dalam masing-masing campuran beton menghasilkan $f_{c}$ ' dan $f_{\text {tspl }}$ yang dirangkum pada Tabel 4. Superplasticizer ditambahkan untuk mencapai kemampuan kerja yang diinginkan.

\subsubsection{Pasir pozolan}

Tiga dari empat spesimen benda uji menggunakan pasir pozolan sebagai pengganti agregat ringan atau bahan pengisi dengan ukuran butiran maksimum 4,76 mm. Satu spesimen lain digunakan sebagai kontrol mutu impact.

\subsubsection{Tulangan baja}

Setiap spesimen berisi empat tulangan penguat baja berdiameter $5,6 \mathrm{~mm}$ sebagai konstruksi rangka pelat dengan diberikan jarak as tulangan $200 \mathrm{~mm}$. Setiap tulangan baja dirancang memiliki ukuran panjang $380 \mathrm{~mm}$. Penggunaan tulangan baja tersebut telah sesuai syarat ACI 549.1R-93. Susunan tulangan baja diilustrasikan pada Gambar 2. Tulangan baja ini memiliki kekuatan leleh 439,81 MPa. Tabel 2 merangkum sifat material dari tulangan baja. 
Tabel 2 Sifat Material dari Tulangan Baja

\begin{tabular}{ccccc}
\hline \multirow{2}{*}{ Diameter } & $\begin{array}{c}\text { Tegangan } \\
\text { leleh, } f_{y}\end{array}$ & $\begin{array}{c}\text { Regangan leleh, } \\
\varepsilon_{y}\end{array}$ & $\begin{array}{c}\text { Tegangan Ultimit, } \\
f_{u}\end{array}$ & $\begin{array}{c}\text { Regangan } \\
\text { Ultimit, } \varepsilon_{u}\end{array}$ \\
\hline$(\mathrm{mm})$ & $(\mathrm{MPa})$ & $(\%)$ & $(\mathrm{MPa})$ & $(\%)$ \\
\hline 5,6 & 439,81 & 0,007 & 580,47 & 0,209 \\
\hline
\end{tabular}

\subsubsection{Kawat jala persegi}

Masing-masing spesimen memiliki jumlah 4 lapis wiremesh (kawat jala) yang digunakan. Setiap lapisan wiremesh dirancang memiliki dimensi penampang $380 \mathrm{~mm}$. Wiremesh ini memiliki bukaan persegi 25,4 $\mathrm{mm}$ dan diameter tulangan 1 $\mathrm{mm}$ yang sesuai dengan ASTM A185-12. Susunan lapisan wiremesh diilustrasikan pada Gambar 2. Wiremesh memiliki kekuatan leleh 562,42 MPa. Tabel 3 merangkum sifat material dari wiremesh.

Tabel 3 - Sifat Material dari Kawat Jala

\begin{tabular}{ccccc}
\hline Grid & $\begin{array}{c}\text { Tegangan } \\
\text { leleh, } \boldsymbol{f}_{\mathbf{v}}\end{array}$ & $\begin{array}{c}\text { Regangan } \\
\text { leleh, } \boldsymbol{\varepsilon}_{\boldsymbol{y}}\end{array}$ & $\begin{array}{c}\text { Tegangan } \\
\text { Ultimit, } \boldsymbol{f}_{\boldsymbol{u}}\end{array}$ & $\begin{array}{c}\text { Regangan } \\
\text { Ultimit, } \boldsymbol{\varepsilon}_{\boldsymbol{u}}\end{array}$ \\
\hline$(\mathbf{m m})$ & $(\mathbf{M P a})$ & $(\boldsymbol{\%})$ & $(\mathbf{M P a})$ & $(\boldsymbol{\%})$ \\
\hline 25,4 & 562,42 & 0,0018 & 1082,19 & 0,0151 \\
\hline
\end{tabular}

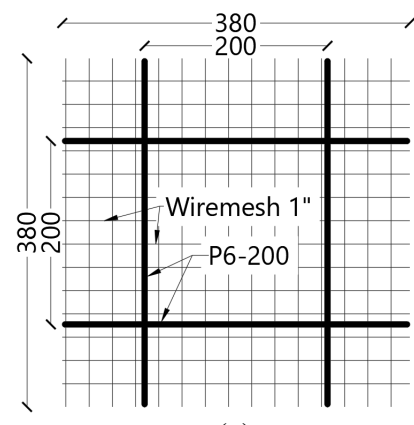

(a)

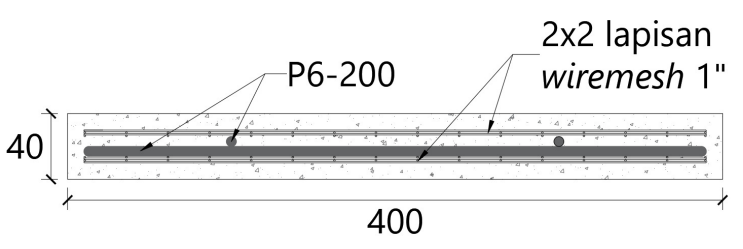

(b)

Gambar 2 (a) Dimensi dan (b) detail penampang spesimen

\subsection{Pengaturan Uji Impact}

Metode yang diterapkan dari ACI 544.2R-89 dan adaptasi pengaturan yang sudah dilakukan oleh (Abdullah, 2016) (Abdullah, 2018). Sebanyak 4 pelat benda uji dilakukan pengujian setelah masa perawatan umur 28 hari. Pengujian dilakukan dengan mekanisme drop-weight test. Menetapkan dan mengatur posisi jatuh bola baja bermassa $3 \mathrm{~kg}$ dari ketinggian $1 \mathrm{~m}$. Spesimen pelat diberi tumpuan balok kayu 5/5 pada ujung sisinya dan dijepit agar tidak bergerak akibat tumbukan. Massa (bola baja) dijatuhkan berulang kali hingga suatu pelat beton mengalami retak hancur (kegagalan) yang ditetapkan dengan pengecualian akibat pantulan tidak diperbolehkan. Sebagian besar retakan dimulai di tengah permukaan tumbukan pada titik jatuhnya bola dan menyebar ke tepi pelat (Abdullah, 2016). 
Catat jumlah pukulan massa yang diterima hingga menyebabkan retak awal (first crack) dan retak hancur (failure crack), mengukur kedalaman kawah (defleksi) selama peristiwa tumbukan dan garis pola perambatan retak secara visual (baik itu retak baru, retak memanjang dan retak celah) serta serapan energi yang dihasilkan.

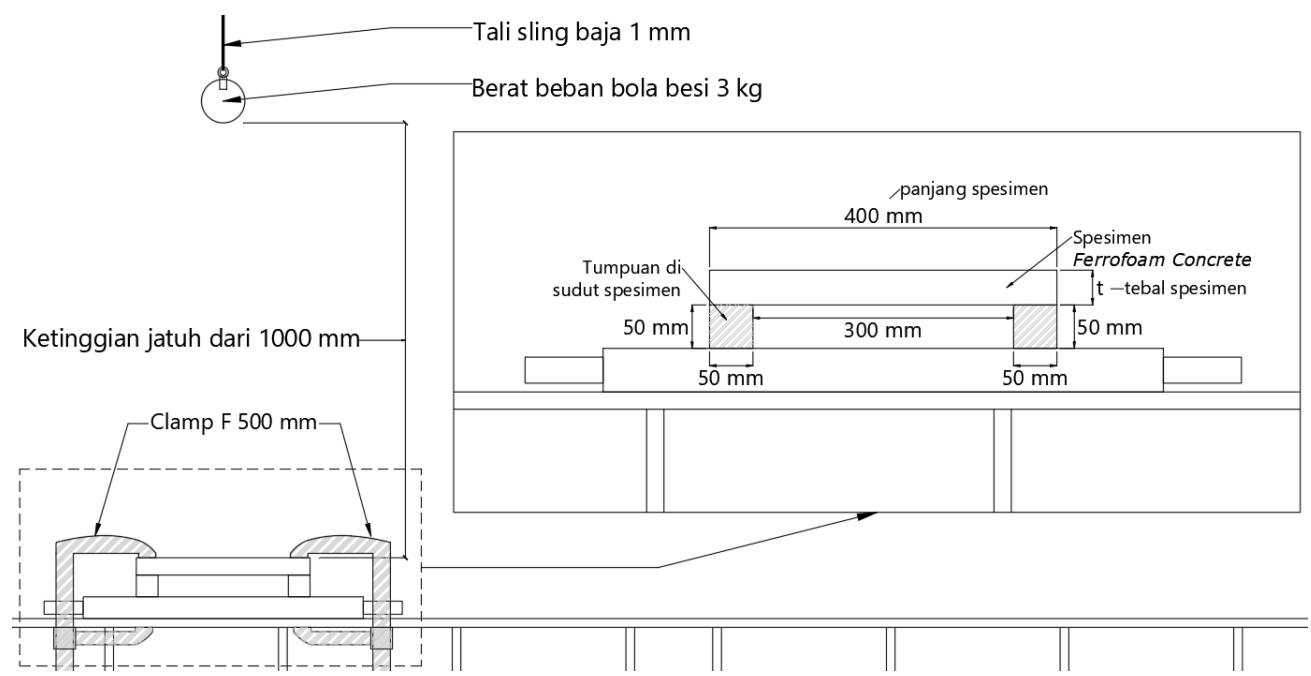

Gambar 3 - Peletakan spesimen dan skema pengaturan alat pengujian impact mekanisme drop-weight test

Penyerapan energi (dalam Joule) dihitung,

$$
E=n \times m \times g \times h
$$

dimana $\mathrm{n}=$ jumlah pukulan, $\mathrm{m}=$ berat beban $(\mathrm{kg}), \mathrm{g}=$ gaya gravitasi, 9,81 $\mathrm{m} / \mathrm{s}$ dan $\mathrm{h}=$ ketinggian jatuh $(\mathrm{m})$. Dalam penelitian ini, tidak ada dilakukan pengukuran regangan dan abaikan reaksi jepit.

\section{Hasil dan Pembahasan}

\subsection{Spesimen di akhir pengujian}

Dalam penelitian ini, ditetapkan massa bola baja $3 \mathrm{~kg}$ dan ketinggian jatuh 1 m. Spesimen pada akhir pengujian ditunjukkakn pada Gambar 4b, yang menampilkan daerah kerusakan akibat pukulan. Pada semua spesimen, pengujian dihentikan ketika beton dari unit pelat telah terlepas. Gambar 4a menunjukkan sisi atas dari hantaman pukulan.

Tabel 4 - Hasil Pengujian

\begin{tabular}{|c|c|c|c|c|c|c|c|}
\hline \multirow{2}{*}{ Spesimen } & \multicolumn{2}{|c|}{ Jumlah pukulan } & \multicolumn{2}{|c|}{ Energi $(\mathrm{J})$} & \multirow{2}{*}{$\begin{array}{c}\text { Defleksi } \\
\text { Runtuh } \\
\text { Total } \\
(\mathbf{m m})\end{array}$} & \multicolumn{2}{|c|}{ Kekuatan } \\
\hline & $\begin{array}{c}\text { Retak } \\
\text { awal }\end{array}$ & Runtuh & $\begin{array}{c}\text { Retak } \\
\text { awal }\end{array}$ & Runtuh & & $\begin{array}{c}f_{c}^{\prime} \\
(\mathbf{M P a})\end{array}$ & $\begin{array}{c}f_{t s p l} \\
(\mathbf{M P a})\end{array}$ \\
\hline $1.4 \mathrm{NP}$ & 1 & 6 & 29,43 & 176,58 & 6,15 & 18,94 & 1,75 \\
\hline $1.2 \mathrm{P}$ & 1 & 8 & 29,43 & 235,44 & 3,12 & 6,22 & 1,08 \\
\hline $1.4 \mathrm{P}$ & 1 & 14 & 29,43 & 412,02 & 8,03 & 11,06 & 1,13 \\
\hline $1.6 \mathrm{P}$ & 1 & 10 & 29,43 & 294,30 & 4,37 & 18,37 & 1,47 \\
\hline
\end{tabular}

Perilaku Pelat Ferrofoam Concrete Dengan dan Tanpa Pozolan Akibat Beban Impact - Muhammad Maulana, Abdullah, Yunita Idris 
Hasil pengujian dirangkum pada Tabel 4. Retakan pertama terjadi karena beban impact. Saat massa jatuh mengenai permukaan pelat terjadi serapan energi yang diterima. Kedalaman defleksi diukur sebagai kedalaman antara permukaan atas pelat akibat tumbukan. Hasil menunjukkan bahwa penggunaan pozolan pada mutu beton ringan lebih baik dalam peningkatan kapasitas impact.
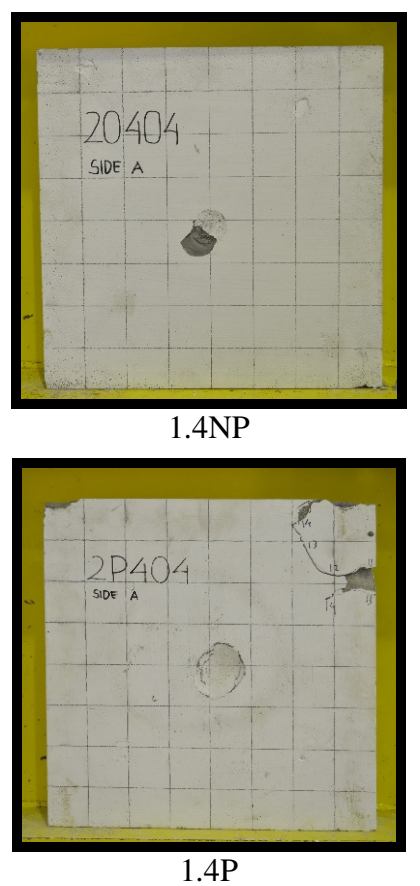

(a) Sisi atas kerusakan pelat ferrofoam concrete

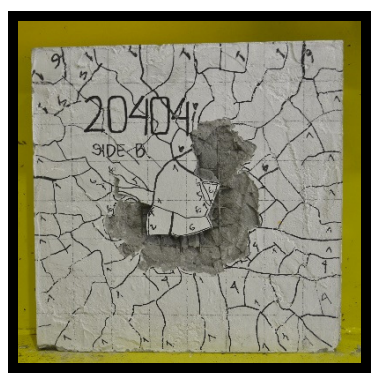

$1.4 \mathrm{NP}$

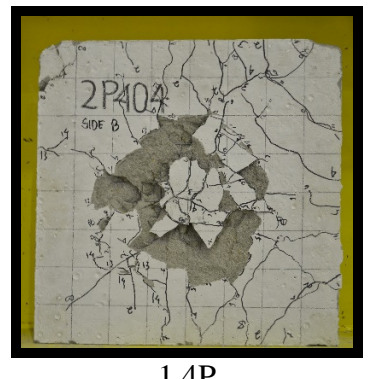

(b) Sisi bawah kerusakan ferrofoam concrete

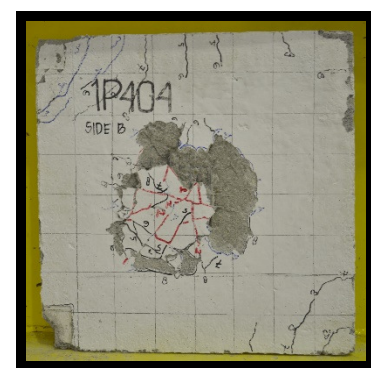

$1.2 \mathrm{P}$

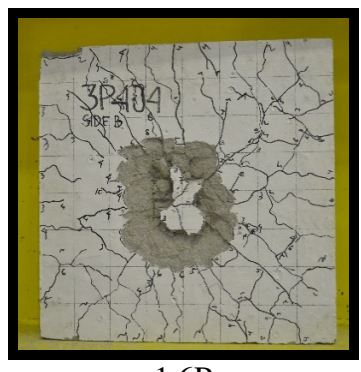

$1.6 \mathrm{P}$

Gambar 4 Kerusakan akhir pelat ferrofoam concrete 


\subsection{Perilaku pelat mutu SG dengan dan tanpa pozolan}

Penggunaan pozolan sebagai agregat ringan pada beton ringan busa dan satu kontrol non pozolan akibat beban impact. Gambar 5a menunjukkan peningkatan kapasitas impact yang tertinggi terjadi pada SG 1.4 menggunakan pozolan dengan penyerapan energi sebesar 412,02 J dan 176,58 J pada SG 1.4 Non Pozolan yang sebagai kontrol impact. Ini artinya dengan penggunaan pozolan dapat meningkatkan jumlah pukulan sebesar 2,33\% dikarenakan adanya lekatan (bond) antara mortar ringan dengan pozolan.

Pengujian kuat tekan dan kuat tarik belah pada Gambar 5b dan 5c menunjukkan grafik garis yang sama. SG 1.4 Non Pozolan atau kontrol mutu menjadi yang tertinggi untuk pengujian kuat tekan dan kuat tarik belah dengan memperoleh kekuatan 18,94 $\mathrm{MPa}$ dan 1,75 MPa yang lebih tinggi dari menggunakan pozolan. Nilai kuat tekan ini digunakan untuk mengetahui mutu beton dan nilai kuat tarik belah digunakan untuk mengetahui retak awal pada pelat ferrofoam concrete yang dijadikan sebagai acuan pada saat pengujian impact.

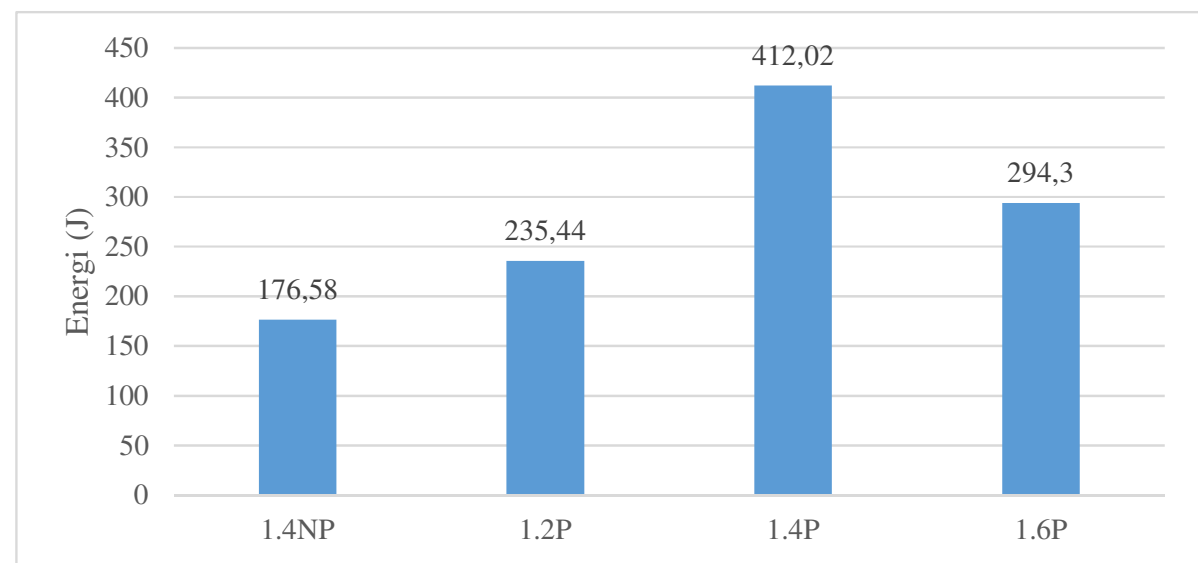

Gambar 5a Energi yang diperoleh mutu SG dengan dan tanpa pozolan saat mengalami keruntuhan

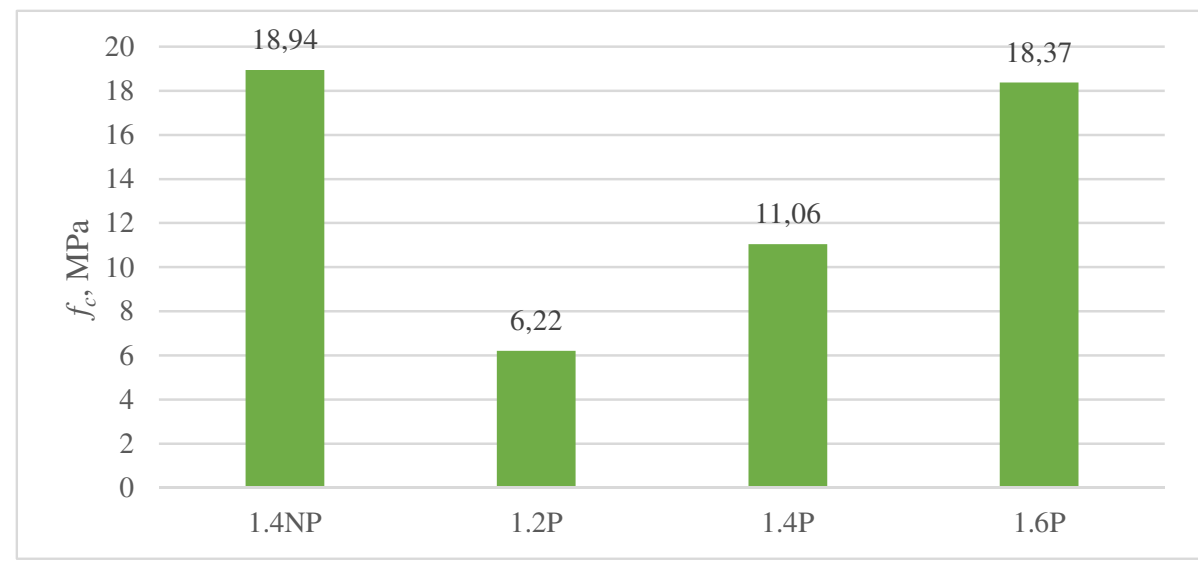

Gambar 5b Kuat tekan yang diperoleh mutu SG dengan dan tanpa pozolan

Perilaku Pelat Ferrofoam Concrete Dengan dan Tanpa Pozolan Akibat Beban Impact - Muhammad Maulana, Abdullah, Yunita Idris 


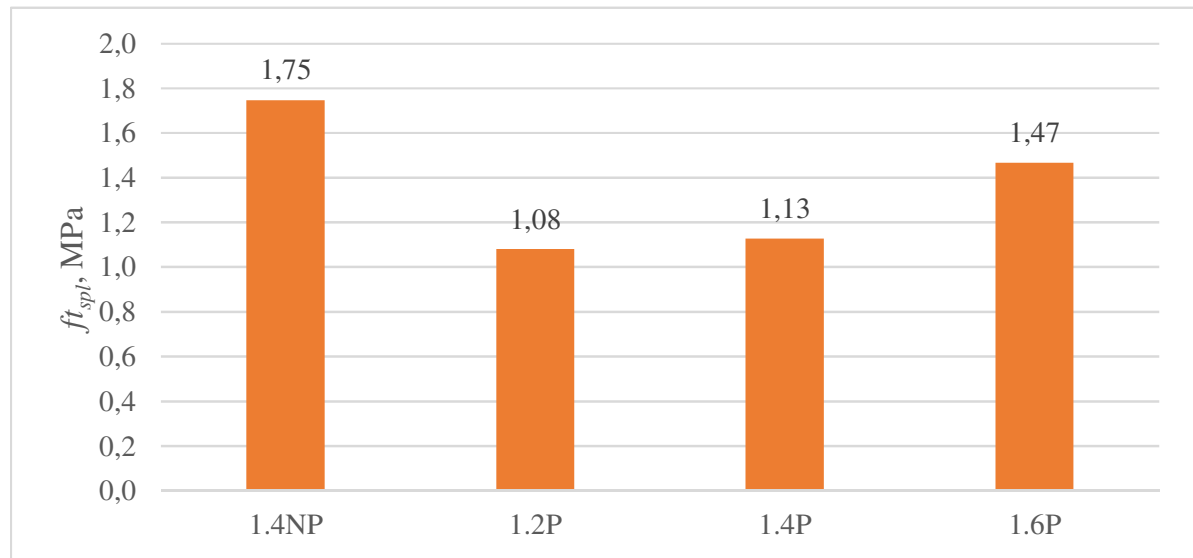

Gambar 5c Kuat tarik belah yang diperoleh mutu SG dengan dan tanpa pozolan

\subsection{Defleksi peristiwa tumbukan pada pelat}

Penentuan kerusakan pelat ferrofoam concrete dengan dan non pozolan akibat beban impact dengan mengukur defleksi setiap kali peristiwa tumbukan.

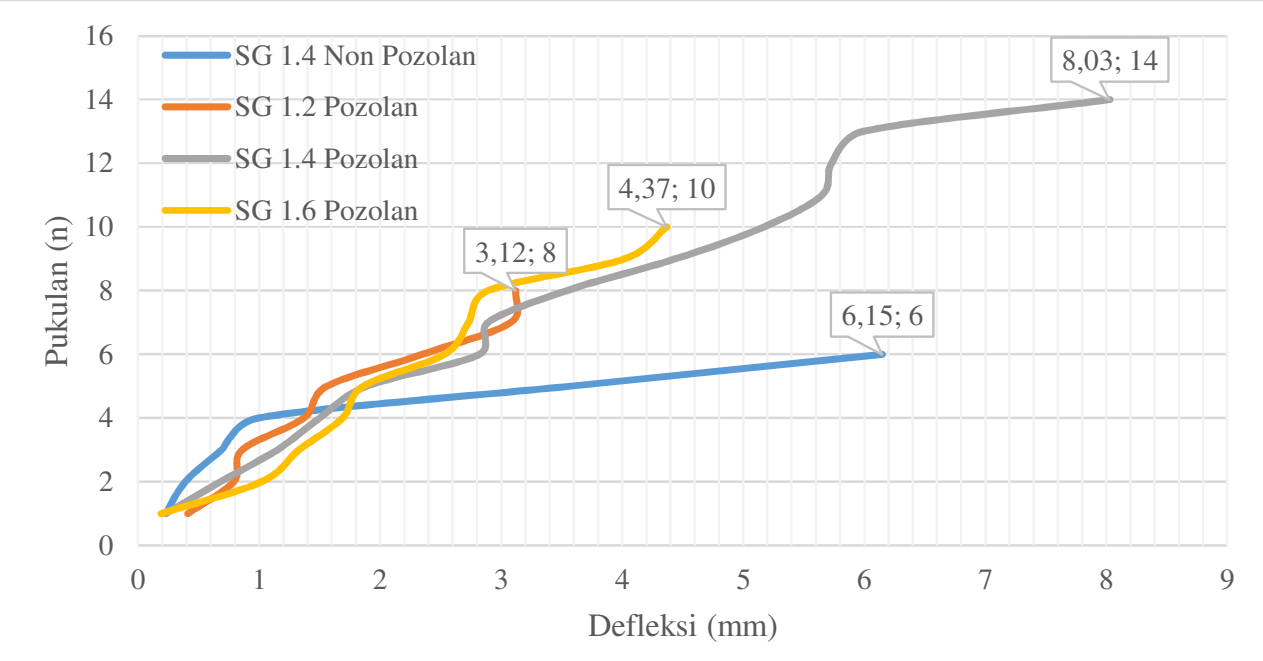

Gambar 6 Jumlah pukulan mutu SG dengan dan tanpa pozolan selama peristiwa tumbukan

Gambar 6 menunjukkan bahwa grafik defleksi yang diperoleh dari jumlah pukulan pada mutu beton penggunaan tanpa dan pozolan tanpa serat. Jumlah pukulan terbesar pada 1.4 Pozolan memperoleh defleksi yang lebih besar dari 1.6 Pozolan dan 1.2 Pozolan serta kontrol 1.4 Non Pozolan.

Defleksi menunjukkan arus grafik yang sama dari pukulan ke-1 hingga benda uji pelat mengalami kegagalan pada mutu SG beton penggunaan pozolan tanpa serat. Berbeda halnya pada kontrol 1.4 Non Pozolan, pukulan ke-5 telah menunjukkan defleksi awal kegagalan dikarenakan sebagai kontrol mutu impact dan tidak memiliki bond (lekatan) antara mortar dengan agregat. Sedangkan mutu SG beton penggunaan pozolan tanpa serat, grafik defleksi hingga mengalami kegagalan masih berada dalam grafik yang sama. Dengan penggunaan pozolan 
pada beton ringan memberikan pengaruh pada lekatan mortar di pukulan ke-5, meskipun defleksi yang dihasilkan masing-masing mutu SG beton berbeda.

Pemisahan kepingan beton atau runtuh total dialami oleh SG 1.4 Non Pozolan pada pukulan ke-6 dengan defleksi 6,15 mm dan SG 1.2 Pozolan pada pukulan ke-8 dengan defleksi 3,12 mm. Pada pukulan ke-10 yang mengalami defleksi terdalam terjadi pada SG 1.4 Pozolan. Meskipun demikian, keruntuhan dengan pemisahan beton SG 1.4 Pozolan terjadi pada pukulan ke-14 lebih lama dari SG 1.6 Pozolan pada pukulan ke-10. Namun, terdapat perbedaan antara perolehan kuat tekan SG 1.6 Pozolan yang tinggi hingga runtuh dengan kapasitas impact.

\section{Kesimpulan dan Saran}

\subsection{Kesimpulan}

Hasil penelitian ini merangkum dari empat benda uji ferrofoam concrete dengan dan tanpa pozolan yang diberi pengujian beban impact. Kesimpulan yang dapat diambil diantaranya dengan penggunaan pozolan pada peningkatan SG, perolehan kapasitas impact yang tertinggi dicapai oleh SG 1.4 dengan penyerapan energi sebesar 412,02 J pada pukulan ke-14. Ini lebih baik daripada penggunaan SG 1.6 dan SG 1.2 yang mencapai pukulan ke-10 dan ke-6. Juga, dengan menggunakan pozolan pada SG 1.4 memberikan kapasitas impact yang baik dibandingkan tidak memakainya. Pada pengujian kuat tekan menunjukkan perolehan tertinggi dicapai SG 1.4 Non Pozolan atau kontrol mutu sebesar 18,94 MPa. Hal yang sama terjadi pada pengujian kuat tarik belah yang memperoleh 1,75 MPa. Adanya pengaruh lekatan antara wiremesh dan mortar ringan baik dengan dan tanpa pozolan yang membuat pemisahan beton dari unit pelat akibat beban impact. Perambatan pola retak dipengaruhi dengan penggunaan pozolan atau tidak adanya sama sekali.

\subsection{Saran}

Rekomendasi pada penelitian ini jika ingin dilanjutkan oleh peneliti lainnya disarankan melakukan variabel mutu SG 1.8 dengan dan tanpa pozolan agar dapat dilakukan perbandingan.

\section{Daftar Kepustakaan}

Abdullah, Afifuddin, M., Huzaim, 2010. Pemanfaatan Bahan Limbah Sebagai Pengganti Semen Pada Beton Busa Mutu Tinggi, in: Konferensi Nasional Teknik Sipil 4. Bali, p. 6.

Abdullah, A.S.K., 2018. Structural Behavior of Ferrocement Panels Exposed to Fire. Sulaimani J. Eng. Sci. 5, 7-17. https://doi.org/10.17656/sjes.10063

Abdullah, A.S.K., 2016. Impact behavior of sandwich ferrocement panels. J. Zankoy Sulaimani - Part A 18, 233-240. https://doi.org/10.17656/jzs.10552 
Abdullah, Bermansyah, S., 2007. Pengembangan Beton Ringan Sebagai Bahan Konstruksi Bangunan Teknik Sipil, in: Seminar Hasil Penelitian TPSDP. Batam.

Abdullah, Takiguchi, K., Nishimura, K., Hori, S., 2003. Behavior of Ferrocement Subjected To Missile Impact, in: Transactions of the 17th International Conference on Structural Mechanics in Reactor Technology. Czech Standard Institution, Prague, Czech Republic, p. 6.

Anonim, 1988. Guide for the Design, Construction, and Repair of Ferrocement. ACI Struct. J. 85. https://doi.org/10.14359/3527 